\title{
Ethnic Insurgency and the Nationwide Ceasefire Agreement in Myanmar
}

\author{
N. Ganesan
}

On October 15, 2015, the government of the Republic of the Union of Myanmar signed a Nationwide Ceasefire Agreement (NCA) with eight of the sixteen ethnic armed groups it had been negotiating with. The aim of the Thein Sein government had been to sign the agreement with all sixteen groups, but this was not realized. One reason why eight of the groups have been left out is the ongoing fighting between the Myanmar military and some of the groups, and the army's unwillingness to involve them in the ceasefire process. Similarly, some of the ethnic armed groups have also indicated that they are unwilling, or not ready, to sign the NCA at this time.

Keywords Myanmar politics, Nationwide Ceasefire Agreement, Myanmar Peace Center, ethnic insurgent groups, Myanmar military

\section{Introduction}

The Myanmar government concluded a Nationwide Ceasefire Agreement (NCA) on October 15 with eight of the country's sixteen ethnic armed groups that it had engaged through the Nationwide Ceasefire Coordination Team (NCCT). This is one of the most important political steps taken since 2010 by the Thein Sein-led government. Other important developments include institutionalization of the ceasefire process through the inauguration of the Myanmar Peace Center. There are, however, a number of challenges facing the inclusion of all the ethnic armed groups in this process. The ongoing conflict with some of the groups, the army's unwillingness to include certain groups, the shifting position of the ethnic groups and the large number of organizations claiming to collectively represent them, and the relative independence of some of the groups all constitute barriers to their full inclusion. Additionally, a confluence of interests between the National League for Democracy (NLD), ethnic groups, and civil society organizations has prompted attempts to collectively challenge the government and the 2008

(C) 2015 The Institute for Peace and Unification Studies, Seoul National University

ISSN 2288-2693 Print, ISSN 2288-2707 Online 
constitution. Those attempts and the potential for reform from within the government were thwarted by the August "coup" against House Speaker Thura Shwe Mann who was viewed as conciliatory to the opposition. Notwithstanding that development the NLD has gone on to win a landslide victory in the November 2015 election.

How well the NCA pans out depends on the joint efforts of the ethnic groups and the government; the agreement will also have a demonstration effect for the groups that have not acceded to it. This article examines the Myanmar government's relationship with the ethnic insurgent groups in the country and the conclusion of the Nationwide Ceasefire Agreement on October 15, 2015. It traces the process of the ceasefire negotiations since 1988 and examines some of the intricacies of the process. The article pays special attention to the difficulties that have attended the process from both ends of the spectrum. While the government was keen to conclude the process as soon as possible and was prepared to make many concessions, the military has been much less forthcoming in dealing with some of the groups. And the ethnic groups themselves are often divided, with many organizations claiming to represent their interests. There are also groups like the Wa who have refused to be involved in the process and the Kachin whose earlier bilateral peace deal with the government has collapsed, resulting in sporadic fighting. Then there are frequent complaints from the Myanmar government side that the "northern factions," a reference to the Wa, Kokang, Kachin, and Mongla groups, are subject to China's influence and support. However, the Thein Sein government has managed to develop a better working relationship with the political opposition, political exiles, and the ethnic insurgent groups. The breakdown in the ceasefire arrangements with the Kachin Independence Organization (KIO) and the ongoing fighting in the Shan states complicated the ceasefire process. The March 2015 fight with the Myanmar National Democratic Alliance Army (MNDAA) in the Kokang region set back the nationwide ceasefire talks. The ethnic ceasefire groups, the political opposition, and civil society groups also hope to enlarge the new-found political space that has opened up since 2010 to push for changes that will better serve their interests in the long run. Concurrently, these groups hope to significantly diminish the influence of the military on the country's politics. This challenge is being closely monitored by the military whose support for President Thein Sein is strong, especially in the light of the evolving political challenges to his discretion and authority emanating from inside and outside parliament. The structural peculiarities of the system also favor the executive and, in particular, the military, which remains the most powerful institution in the country. Most of the country's political executive is drawn from the ranks of retired military officers and as such it has interests that are convergent with those of the armed forces. How the situation will play itself out after the new government led by the NLD is formed remains to be seen, but early indications are that President Thein Sein and the 
military have acknowledged the NLD's overwhelming victory in the election and they have even offered their congratulations to its leader, Aung San Suu Kyi. They have also offered to work with her during the period of political transition.

This article is divided into four main sections. The first section details the institutionalization of the peace process while the second identifies the major challenges involved in the conclusion of the Nationwide Ceasefire Agreement (NCA). The third section looks at the proliferation of ethnic organizations claiming to represent the armed groups and their collective alignment with other groups opposed to the present political situation. The fourth section focuses on the current situation and the position of the military, and this is followed by a short conclusion.

\section{Institutionalizing Peace Making}

The military government that came to power in Myanmar after staging the 1962 coup collapsed in 1988. This happened just before the implosion and collapse of the Burmese Communist Party (BCP) in 1989, which in turn led to the formation of two more ethnic insurgent armies representing the Wa and the Kokang ethnic groups. Between then and 2013, in an effort to stabilize the domestic political situation, the military junta signed ceasefire agreements with fourteen more ethnic insurgent groups that were in turn allowed to keep control of a designated contiguous territory whilst retaining their weapons. ${ }^{1}$ At the same time, the junta mounted major military offensives against groups with which it had not signed ceasefire agreements. The elected government that has been in power since 2010 is predominantly led by senior military officers. The most senior officers of the State Peace and Development Council (SPDC, the military government in power before the elections), generals Than Shwe and Maung Aye, retired from politics and handed over power to Thein Sein, the incumbent president.

The Myanmar Peace Center (MPC) was inaugurated in October 2012 in Yangon and currently serves as the government's vehicle for negotiating with the ethnic armed groups in order to achieve long-term accommodation with them and resolve the issue of having private armed groups within the country (Ganesan 2014). President Thein Sein was one of the early architects and supporters of the process of engaging the ethnic insurgent groups in the peace process. The MPC serves as the central clearing house for peace negotiations. Its board is chaired by the government's chief ceasefire negotiator, U Aung Min, who previously served as union minister for rail transportation.

The MPC's most significant and important mandate is the conclusion of a Nationwide Ceasefire Agreement with all the ethnic insurgent armies. The government has been quite successful in this regard, bringing into the fold three out of the four remaining such groups to sign ceasefires in 2012. These were the 
Chin National Front (CNF), the Karen National Union (KNU), and the Karenni National Progressive Party (KNPP). The Kachin Independence Organization (KIO) and its armed wing the Kachin Independence Army (KIA), however, did not sign a ceasefire agreement with the current government after their agreement with the SPDC lapsed. As a result, there has been sporadic fighting between the army and the KIA since June 2011. The most recent major skirmish occurred in September 2015 and it threatened the ongoing peace talks as well as the provision of supplies to internally displaced persons. The KIA also accuses the government of attempting to control supply routes in order to cut off the KIA stronghold and headquarters at Laiza. In addition to this major breakdown, there are occasional skirmishes in the Shan states involving the Tảang National Liberation Army (TNLA, the armed wing of the Palaung State Liberation Front) and the Revolutionary Council of the Shan States (RCSS), previously referred to as the Shan State Army-South (SSA-S). The TNLA, together with the Arakan Army (AA), was also involved in supporting the Myanmar National Democratic Alliance Army (MNDAA) of the Kokang ethnic group from March 2015 when it attacked government troops in Laukkaing (to be discussed later).

The approach of the MPC and the Thein Sein government to the ceasefire negotiations consists of consolidating the ongoing process at three levels. In the first instance, the ceasefire was negotiated at the regional level. Subsequently, the agreement was endorsed at the union level, in accordance with the geographical and administrative division of the country. Finally, the plan was that all the ceasefire groups would convene a meeting with the government where a nationwide agreement would be signed. The last stage of the agreement was meant to emulate the historic Panglong Agreement, signed with the ethnic groups by General Aung San in 1947. The current agreement, scheduled for signing by 2014, was postponed several times until a draft agreement was signed in March 2015 followed by the signing of the final agreement in October. However, only eight out of the sixteen ethnic insurgent groups that were engaged by the government eventually signed the NCA.

\section{Background to the Nationwide Ceasefire Agreement (NCA)}

The Myanmar government began to sign ceasefire agreements with the ethnic groups from as early as 1989 following the collapse of the BCP. The earliest of these agreements were signed with the United Wa State Army (UWSA) and the Myanmar National Democratic Alliance Army (MNDAA) that represented the Kokang ethnic group. Both groups were previously the sword arms of the $\mathrm{BCP}$, and the authorities were anxious to contain the situation following the collapse of the Burma Socialist Programme Party (BSPP) government under General Ne Win at around the same time (Steinberg 2001). The two groups also operated 
close to the Chinese border and the UWSA has acquired notoriety as a major supplier of natural and synthetic drugs in the region and beyond (Chin 2009, 222-4; Roberts 2010, 84-86). The MNDAA was routed by the military following a conflict in 2009 that led to the ouster of the group's leader, Peng Jia Sheng, from Myanmar. Chinese intelligence sources suggest that pressure was brought to bear on the Myanmar military after Kokang-manufactured weapons were found in Tibet and other restive areas of China. As for the Wa, they are now by far the largest of the ethnic armies after having commissioned a fourth brigade in Panghsan in 2010 (Ganesan 2011, 108).

The Myanmar government's approach to dealing with the ethnic armies is to sign an initial ceasefire agreement. This agreement respects the groups' right to control clearly demarcated contiguous areas and to continue bearing arms. It is hoped that afterwards, through an admixture of negotiations for political rights and accompanying development in the region, the armies will be disbanded. The government's original plan under the SPDC was to demobilize the soldiers from these groups and have them join a Border Guard Force that had elements of both the regular army and the ethnic insurgents. However, the government had only limited success with this scheme. The larger groups, and in particular the Kachin, Karen, Shan, and Wa, rejected it outright and the government is trying to find new ways to resolve the situation (South 2008, 11).

The agreements reached thus far would not have been achieved without very strong commitment on the part of the government and the able leadership exercised by the lead negotiators of the two government-appointed teams. Especially significant in this regard is the role played by U Aung Min. The teams' direct appointment by President Thein Sein and their conciliatory approach has won them much leeway and goodwill from the ethnic armed groups, who with rare exceptions went on to sign ceasefire agreements (Kyaw 2012). However, the Nationwide Ceasefire Agreement involving all the ethnic armies remained elusive for some time despite the reasonably high levels of goodwill and trust achieved between the government and the ethnic groups.

The first problem that disrupted the process was the resumption of hostilities between the military and the KIA in Kachin state. This setback has wider implications for the ceasefire process in general. In fact, the ethnic groups have significantly consolidated themselves and now appear to be utilizing a strategy of bargaining collectively that often supports the groups fighting the government. This strategy is especially favored by the United Nationalities Federal Council (UNFC), an organization that brings together eleven of the country's ethnic armed groups. Additionally, there appears to be a broad-based agreement between the political opposition, the ethnic ceasefire groups, and civil society groups that they have convergent sociopolitical interests and that these are best served by working together against the government. In this regard, the government appears to be facing a united front of sorts, consisting of disenchanted local groups. 
The KIA previously had a ceasefire agreement with the government that unfortunately broke down in mid-2011. The insurgent army is believed to have a troop strength of approximately eight thousand and is deployed in Kachin state, a state that shares a long border with China. Both sides have blamed the other for the collapse of the truce. In December 2012 there was a serious escalation of the conflict following the KIA's refusal to vacate from an area after it was served notice by the military. Consequently, shortly after Christmas, government forces used helicopter gunships and aircraft to bomb KIA positions. More recently, the TNLA and AA have also supported the KIA in its fighting against government troops. An official from the MPC, on condition of anonymity, noted that both the secondary groups were nourished and armed by the KIA over time just like the New Mon State Party (NMSP) and the Karenni National Progressive Party (KNPP), with pressure brought to bear on them through the UNFC in which the KIA maintains a strong position as one of the largest groups. The TNLA does not as yet have a bilateral ceasefire agreement with the government and is therefore behind the other groups with regard to the ceasefire process. Such a bilateral agreement is a prerequisite of involvement in collective agreements.

There are now approximately seventy thousand internally displaced persons in government-controlled refugee camps and another fifty-five thousand in areas controlled by the KIA. The latter is headquartered in Laiza, near the border with China, and there have been reports of shells landing on the Chinese side where there are approximately five thousand refugees. China is keen to see the situation resolved peacefully and not threaten security in neighboring Yunnan Province that typically bears the brunt of spillovers from conflict (Ganesan 2010, 8-9; 2011, 108-9). ${ }^{2}$ In a round of negotiations conducted in Ruili in January and March 2013, China sent high-ranking representatives from the Ministry of Foreign Affairs and the military to the meeting to indicate its interest in resolving the situation. It has also urged the ethnic armed groups to make progress in signing a ceasefire agreement (elevenmyanmar.com, May 15, 2014).

More recently, the government shelling of a KIA cadet training school in November 2014 that killed twenty-three trainees placed the entire peace dialogue in jeopardy and heightened tensions between the government and the KIA (kachinnet.net, November 22, 2014; Nation, November 21, 2014). While the army claims that the shelling was accidental, the KIA is not convinced and regards the incident as a "warning shot." The KIA is spread over a large area in Kachin state and many of its operational units have over time acquired fairly high levels of independence from the central organization. As a result of such independence, coordination and structured negotiations with the KIA are more challenging than with smaller organizations. The Karen National Union (KNU) also has operational units with similar relative independence.

The conflict with ethnic minority groups was significantly ratcheted up in March 2015 when the Myanmar National Democratic Alliance Army (MNDAA) 
stormed the city of Laukkaing and fought a major battle with government troops. The MNDAA and its leader Peng Jia Sheng, who had been driven out to China in 2009, sought to regain control of the city in the Kokang region. Government forces were caught off guard and suffered heavy casualties in the initial assault as well as the subsequent mop-up operations that lasted for more than three months (Radio Free Asia, March 19, 2015). Assisted by air strikes against the rebels, government troops were able to retake high ground near the Chinese border. ${ }^{3} \mathrm{~A}$ number of complications arose as a result of this skirmish.

The first complication was that this fighting set back the Nationwide Ceasefire Agreement signing date. The second complication was that the military refused to include the MNDAA in the ceasefire process and is now dedicated to the group's destruction. The significant loss of life and face for the military has hardened its position vis-à-vis the MNDAA as well as the TNLA and the AA that fought alongside the MNDAA. Consequently, these three groups faced resistance from the military against their inclusion in the nationwide ceasefire talks, whereas the ethnic groups, and especially the KIA, demanded their inclusion (Irrawaddy, June 3, 2015). The military is also unwilling to engage three more groupsthe Wa National Organization, the Lahu Democratic Union, and the Arakan National Council. These additional organizations represent splinter groups without military capability and the army refuses to deal with them. Interestingly, in the Myanmar context, ethnic insurgent groups often have a fighting army as well as a political party that competes in elections. In this way, they hope both to benefit from the electoral process in ethnic areas where they have strong support and representation and to remain prepared for military conflict with the army in operational areas.

In the meantime, there has been a proliferation of organizations on the ethnic side of the equation that makes coordinated positions more difficult to achieve. So, for example, in February 2011, a total of eleven ethnic armed ceasefire groups-including the Kachin Independence Organization (KIO), the New Mon State Party (NMSP), the Shan State Army-North (SSA-N), the Karenni National Progressive Party (KNPP), the Chin National Front (CNF), the Karen National Union (KNU), and five smaller groups representing the Lahu, Arakan, $\mathrm{Pa}-\mathrm{O}$, Palaung, and a Wa splinter group-formed the United Nationalities Federal Council (UNFC) in order to collectively coordinate their position with the government (Tin 2013,6). Whereas the general level of trust between the ceasefire groups and the government is quite high, groups like the All Burma Students Democratic Front (ABSDF), the KIO, the Revolutionary Council of the Shan States (RCSS), and the United Wa State Army (UWSA) have not always been agreeable or cooperative, and sporadic fighting has broken out from time to time in Kachin and Shan states. The groups are also attempting to project a united front in order to have much stronger negotiating terms and positions, albeit the KNU withdrew from the UNFC and then went on to become the anchor ethnic 
group for the NCA (elevenmyanmar.com, September 3, 2014). The ABSDF then followed the lead of the KNU and articulated a similar position (Bangkok Post, August 19, 2015). The latest development in this regard was the formation of the Nationwide Ceasefire Coordination Team (NCCT) that was cobbled together in October 2013 after a meeting in Laiza. The NCCT draws its membership and office bearers from the larger ceasefire groups and has spearheaded meetings with the MPC's Union Peacemaking Working Committee (UPWC).

In February 2014, the ethnic groups set up the Pyidaungsu Institute (PI) in Chiangmai to coordinate their various positions. Office bearers of the PI are drawn from the major ethnic groups, and its stated policy position is to provide a common platform for dealings with the MPC (Ganesan 2014, 134-5). The ethnic groups' situation is also complicated by a proliferation of other organizations, including the Nationalities Brotherhood Federation (NBF) that brings together twenty ethnic groups. This group announced in May 2014 that it had prepared a draft document for the establishment of a federal union (elevenmyanmar. com, May 14, 2014). Since May 2015, following the Panghsan Summit hosted by the UWSA, another new negotiating team has been formed to deal with the government (elevenmyanmar.com, June 25, 2015). This new group insisted on changes to the March 2015 draft ceasefire agreement to which the NCCT had previously agreed. Both the government negotiating team and the military rejected this new demand and probably viewed it as an attempt by the UWSA to sabotage the ceasefire negotiations. The UWSA is mindful of the fact that it will remain one of the few groups left out of the nationwide ceasefire if and when it is implemented and that would make it isolated and much weaker in future negotiations with the government and the military. It currently enjoys relative autonomy with little disturbance from either China or Myanmar and is keen to consolidate that position for the long haul. The more entrenched it becomes over time, the harder it will be for the military to fight it. In any event, it is the most significant "northern faction," with Chinese leadership and quiet support from China thus far.

An additional complication was the NCCT's position that the ceasefire talks and agreements should include all ethnic groups, which made the situation impossible from the viewpoint of the military. The UWSA's Panghsan Summit of May 2015 complicated the situation even more. During that summit, the twelve ethnic armies from the NCCT supported the Wa demand for an independent state. Additionally, the summit called for an end to military offensives in Kokang, Shan, and Rakhine states as well as amendments to the 2008 constitution and the development of a genuine federal union (elevenmyanmar.com, May 8, 2015).

These developments made it extremely difficult for the government negotiating team to conclude an inclusive ceasefire arrangement and for the military to support it. The ethnic groups also appear to have a poor understanding of the evolution and politicization of ethnicity in Myanmar. Equally, they seem to 
misunderstand how federal governments work in practice and tend to mistakenly think that a federal arrangement will allow them to control territories and retain private armies (Taylor 2015). In the face of all these difficulties, a total of eight groups led by the KNU agreed to and then signed the NCA in October 2015 after an ethnic summit meeting in Chiangmai (elevenmyanmar.com, October 2, 2015). The seven groups are the KNU, the Democratic Karen Benevolent Army (DKBA), the Karen National Liberation Army (KNLA), the Chin National Front (CNF), the Arakan Liberation Party, the All Burma Students' Democratic Front (ABSDF), the Pa'o National Liberation Organization (PNLO), and the Revolutionary Council of the Shan States (RCSS). A "joint-implementation coordination meeting" was subsequently held a day after the signing of the NCA. During that meeting a joint monitoring committee and a peace development committee were set up to ensure that the NCA succeeds.

The conflict with the MNDAA has also strained Myanmar's bilateral relations with China. The Kokang are not only ethnic Chinese like the Wa but also operate close to the Chinese border. As a result of this situation, at the height of the fighting, some seventy thousand refugees streamed across the border into China. Importantly, Myanmar's bombing of a hut inside Chinese territory led to the deaths of five Chinese citizens. ${ }^{4}$ China also reported that stray artillery shells had fallen on its side of the border. As a result, the Chinese significantly reinforced the border and deployed fighter aircraft in the region, clearly signaling their resolve to prevent untoward incidents. The Myanmar government quickly defused the situation by apologizing for the deaths and offering compensation to the tune of 70,000 yuan per person. However, it also urged the Chinese government to deal with the MNDAA and not let its territory be used by the ethnic group (elevenmyanmar.com, May 20, 2015).

\section{Coordination between Ethnic Groups and Other Political and Social Opposition Groups}

In other developments, the ethnic groups held a coordination meeting in Mae Sot, Thailand, with the NLD, the 88 Generation Peace and Open Society, and the successful candidates in the 1990 general election (elevenmyanmar.com, June $29,2014)$. The latest development in this apparent strategic alliance between the NLD and the ethnic groups is the party's formation of a work cooperation group with the Union Nationalities Alliance (UNA) (elevenmyanmar.com, September $8,2014)$. In the meantime, the NLD announced that it would not stand against its ethnic minority allies in the November 2015 election while the UNA announced that it would call for a grand meeting to discuss an opposition alliance election strategy (elevenmyanmar.com, July 14 and 15, 2015). While the NLD had made similar strategic pacts with other opposition groups, it indicated that it 
would give priority to its own party members in electoral contests against the government's Union Solidarity and Development Party (USDP). The loosening of political control in Myanmar has also led to a surge of civil society organizations which are increasingly joining together to oppose the government. These opposition activities include the ongoing, sometimes violent, demonstrations by farmers, villagers, townsfolk, and even squatters protesting against the takeover of land by the military, government agencies, and business tycoons for personal, institutional, and industrial use. Land disputes have become a cause célèbre for activists, political parties, civil society organizations, and even foreign lobbyists. Such groups are especially interested in lobbying the public for amendments to specific provisions in the 2008 constitution that give the military 25 percent of all seats in parliament and require a more than 75 percent vote in parliament to amend the constitution. As things stand, as long as the military casts a block vote, constitutional amendment is impossible.

The opposition's united front strategy in dealing with the government and attempting to engage members of the political elite, in particular Lower House speaker Thura Shwe Mann, has backfired. On August 13, the government announced that Thura Shwe Mann had been removed as USDP chairman and replaced by Htay Oo, an ally of President Thein Sein. Shwe Mann's friend, the party's secretary-general, Maung Maung Thein, was also removed and replaced (Nation, August 14, 2015). The reason given by the president's spokesperson for this dramatic replacement that involved a security siege of the USDP headquarters in Naypyitaw was that Shwe Mann had made questionable decisions that served his own personal interests rather than those of the party or the country. Such decisions involved working to amend the constitution so as to reduce the military's role in parliament, working with the political opposition, and using his power to put pressure on other party officials who were working against intra-party democracy (Reuters, August 15, 2015). He is also reported to have opposed the selection of many retired military officers as candidates in the November 8 election. Whereas Shwe Mann continues to remain the Lower House speaker, he has clearly lost the support of the USDP and the military. Consequently, he is no longer in a position to influence domestic politics, despite being hailed by Aung San Suu Kyi as an ally in the democratization process.

In fact, Aung San Suu Kyi urged the ethnic groups in September 2015 not to rush into the peace deal with the government but rather to "work slowly on a long-term agreement that would ensure long-lasting stability (Channel NewsAsia, September 6, 2015). She also promised to hold peace talks with the groups after the NLD's likely overwhelming victory in the November 2015 election (elevenmyanmar.com, September 6, 2015). Unfortunately for Aung San Suu Kyi, the ethnic minority groups' distrust of the Bamar majority runs very deep. This was confirmed by Saw Than Myint, an ethnic Shan and founder of the Federal Union Party (FUP), when he indicated in a recent interview that 
ethnic groups and their representatives continue to harbor suspicions against the Bamar, including members of the NLD (Straits Times, October 19, 2015). The reality is that ethnicity has become reified in Myanmar and unscrupulous elites have historically exploited it for their own purposes rather than trying to forge a common national identity (Taylor 2015).

\section{The Current Situation and the Military's Position}

While much accommodation and progress has been achieved in the relationship between the government and the ethnic groups, the end goal of an inclusive peace process with the ethnic insurgent groups has remained elusive. In the past, the government tended to place the cart before the horse and identified preferred dates for the signing of the NCA without taking into account the realities on the ground. It has since become more sophisticated in its approach, but differences continue to exist. First, the Wa have indicated in no uncertain terms that they see no necessity to sign another agreement when their existing one is working well. In fact, the UWSA went on to make it more difficult for the other groups to sign the NCA by introducing revisions to the previous draft that the ethnic groups had agreed to in March 2015.

The second difficulty is the ongoing unresolved conflict between the military and the KIA. Other groups involved in sporadic fighting include the RCSS and the TNLA. The MNDAA's attack on government forces in Laukkaing in March 2015 and the TNLA and AA's support for it have also alienated them from the other groups. The TNLA has no peace agreement with the government, and the military is unwilling to accede to an agreement with the MNDAA, the TNLA, and the AA. The three other groups with which it has no interest in signing agreements are the Wa National Organization, the Lahu Democratic Union, and the Arakan National Council. The large loss of life and face inflicted on them by the MNDAA means that the military is committed to defeating the MNDAA with armed force. The extension of the state of emergency imposed in Kokang in response to the March fighting effectively means that the military controls the area and the situation is not subject to civilian or political interference. In this regard, it should be remembered that the military is above civilian political control on issues of peace and security that threaten the state.

The military is the largest and most influential domestic player in Myanmar. It is the most organized actor and has disproportionate resources at its disposal compared to its competitors. Most members of the current cabinet are ranking military officers who have simply donned civilian clothes. The mass-based organization that represents the military's political interests is the USDP, which was simply converted from the previous mass organization, the Union Solidarity and Development Association (USDA). In structural terms, the military has 
25 percent representation in the Union government as well as the regional parliaments. The parliament requires an absolute majority of more than 75 percent in order to amend the 2008 constitution and the military is likely to cast a block vote to veto any prospects of such a change. An attempt by ethnic minority MPs to allow for constitutional change with the approval of two-thirds of the parliament to bypass the military veto came to naught (elevenmyanmar.com, June 25, 2015).

The military is also free of parliamentary oversight and in control of the home affairs, defence, and border areas portfolios while holding six of the eleven seats on the National Defence and Security Council. The constitution has also created a strong executive in that the president has the power to appoint or remove the central and subsidiary governments (Taylor 2009, 497). The president may also declare a state of emergency, assume all powers, and empower the military to maintain order. Interestingly, the military may also act independently to protect state sovereignty and ensure compliance with the constitution (Taylor $2009,498)$. The military has also clearly indicated that it does not favor changing the 2008 constitution (elevenmyanmar.com, November 14, 2014).

Thein Sein does seem to command the support of the military and that of Senior General Min Aung Hlaing who heads it. In terms of their backgrounds and social ties in the military, they have convergent interests, unlike Shwe Mann who seems to have broken ranks. In fact, Min Aung Hlaing has even been suggested as a potential replacement for Thein Sein, though he has remained coy about his plans. In a recent interview in Singapore, he was reported as having said that Myanmar is not ready for a reduced role for the military since the country is still a young democracy (Wong 2015a). He subsequently added that although the military would not unilaterally stage a coup, it would step in to help restore law and order if a state of emergency were to be declared by the president (Wong 2015b).

\section{Conclusion}

The ongoing changes in Myanmar since the 2010 national election have led to a number of positive developments in the country. These changes have also drawn the country away from the kind of military authoritarian rule that obtained in the aftermath of the collapse of the BSPP government in 1988. One important political development is the signing of the NCA with eight of the country's sixteen ethnic insurgent armies. The NCA led in turn to three of the ethnic groups being removed from the government blacklist. They are the Karen National Union (KNU), the Restoration Council of the Shan State/Shan State Army-South (RCSS/ SSA-S), and the All Burma Students' Democratic Front (ABSDF), all of which can now operate freely (elevenmyanmar.com, October 14, 2015). This development is 
important in the country's political transformation, although the recent conflict with the MNDAA and the remaining ethnic groups' unwillingness to sign the NCA have set it back. Especially contentious for the military is the inclusion of the MNDAA and its comrades-in-arms, the TNLA and AA.

It is hoped that the KNU's lead in signing the NCA together with seven other groups in October will pave the way for the remaining groups to follow suit. An important factor in this will be how the post-signing political dialogue scheduled for January 2016 proceeds. It is likely that the other groups will take their cue from this. In fact, this version of the NCA was agreed to by all the signatories some two years ago. The UPWC was hoping to extend the agreement to cover the remaining eight groups that comprise the NCCT (the body that has been negotiating with the government), and especially the "northern factions," but to no avail. Of the remaining six groups, the government requires the TNLA to first sign a bilateral agreement and the MNDAA to completely surrender before any dialogue can take place. And while there has been a breakdown in the peace process with the KIO, the government still recognizes it as a signatory to a 1994 bilateral ceasefire agreement (Aung 2015).

An important part of the NCA is the convening of a Nationwide Ceasefire Agreement Joint Implementation Coordination Meeting that will in turn form the Joint Ceasefire Monitoring Committee. This committee will then be tasked with fleshing out the details that have been agreed to in the NCA. The NCA itself is a lengthy twelve-page-long document divided into seven chapters that has been signed by the ethnic groups and government representatives as well as national and international witnesses. The government's decision to include the EU and Japan as sponsors of the MPC and rightful signatories to the NCA raised the ire of China even as the document was about to be signed. Other prominent signatories are China, India, and Thailand, all of which share borders with Myanmar, and the UN. Finally, it should be remembered that the NCA is a process as well as a product and how well the process plays out will determine its success. The remaining groups must be included into the process for it to be fully representative of all the ethnic armed groups.

\section{Notes}

1. In addition to the Wa and the Kokang, the groups that had officially negotiated peace agreements with the government were the All Burma Students' Democratic Front (ABSDF), the Arakan Liberation Party (ALP), the Chin National Front (CNF), the Democratic Karen Benevolent Army (DKBA), the Karen National Union (KNU), the Karen National Liberation Army Peace Council (KNLA), the Karenni National Progressive Party (KNPP), the New Mon State Party (NMSP), the National Socialist Council of Nagaland-Khaplang, the Pa-Oh National Liberation Organization (PNLO), the Restoration Council of Shan State (RCSS)/Shan State Army-South (SSA-S), and the Shan State Progressive Party (SSPP)/ 
Shan State Army-North (SSA-N).

2. Interestingly, it was reported that ammunition bearing Chinese markings was recovered from the conflict areas by the Myanmar military. A government spokesman, however, dismissed the notion that the Chinese government supports the KIA. Instead he alluded to the ammunition coming from Yunnan Province.

3. A well-connected and influential businessman whom I met in Yangon in May informed me that a large number of government soldiers were killed when the MNDAA staged a night ambush from defensive positions using night-vision goggles. This large number of casualties was acknowledged by negotiators at the MPC.

4. A ranking member of the MPC informed me in May that the five Chinese who were killed were actually MNDAA fighters who had crossed the border and taken refuge in the hut. There were also allegations of the MNDAA using Chinese mercenaries to fight the Myanmar army.

\section{References}

Aung Naing Oo. 2015. "Myanmar's Ethnic Armed Groups Serve Complex 'Alphabet Soup"' Nikkei Asian Review, October 12-18, 2015.

Chin, Ko-lin. 2009. The Golden Triangle: Inside Southeast Asia’s Drug Trade. Ithaca: Cornell University Press.

Ganesan, N. 2010. “Myanmar's Relations with Its Near Neighbours." International Studies Review (10) 1: 1-24.

Ganesan, N. 2011. "Myanmar-China Relations: Interlocking Interests but Independent Output." Japanese Journal of Political Science 12 (1): 95-111.

Ganesan, N. 2014. “The Myanmar Peace Center: Its Origins, Activities, and Aspirations.” Asian Journal of Peacebuilding 2 (1): 127-141.

Kyaw Yin Hlaing. 2012. "The Unexpected Arrival of a New Political Era in Myanmar." Unpublished manuscript.

Roberts, Christopher. 2010. ASEAN's Myanmar Crisis: Challenges to the Pursuit of a Security Community. Singapore: Institute of Southeast Asian Studies.

South, Ashley. 2008. Civil Society in Burma: The Development of Democracy amidst Conflict. Honolulu: East-West Center.

Steinberg, David I. 2001. Burma: The State of Myanmar. Georgetown: Georgetown University Press.

Taylor, Robert H. 2009. The State in Myanmar. Singapore: NUS Press.

Taylor, Robert H. 2015. "Refighting Old Battles, Compounding Misconceptions: The Politics of Ethnicity in Myanmar Today." ISEAS Perspective (Institute of Southeast Asian Studies, Singapore), no. 12.

Tin Maung Maung Than. 2013. "Inter-Ethnic Conflict and Peacemaking in Myanmar." ISEAS Perspective (Institute of Southeast Asian Studies, Singapore), no. 12.

Wong, May. 2015a. "Myanmar not Ready for Reduced Role in Parliament: Army Chief." Channel NewsAsia. January 20.

Wong, May. 2015b. “Myanmar's Military Says Will not Unilaterally Stage a Coup." Channel NewsAsia. January 21. 